\title{
Alstrom Syndrome
}

National Cancer Institute

\section{Source}

National Cancer Institute. Alstrom Syndrome. NCI Thesaurus. Code C84549.

A rare autosomal recessive syndrome caused by mutations in the gene ALMS1. Signs and symptoms include blindness, obesity, hearing loss, endocrine abnormalities, cardiomyopathy and congestive heart failure, hepatic and renal failure. 